\title{
Women as the Oppressed Lot in theGod of Small Things
}

\author{
Shubha Prakash ${ }^{1} \&$ Sujata ${ }^{2}$ \\ 1Research Scholar FET, MRIU, Faridabad\& Associate Professor, Echelon Institute of Technology, Faridabad, \\ Haryana, India \\ 2Assistant Professor, Faculty of Commerce and Humanities, MRIU, Faridabad, Haryana, India
}

\begin{abstract}
In the orthodox and conservative society like ours, women have always been undervalued due to patriarchal assumptions. They have been tutored that their greatness lies in their sufferings and therefore, happiness of others is always prioritized to their own. In fact, their perceptions of their aspirations and expectations are within the framework of Indian social and moral commitments. In this paper, an attempt is made to study the lot of women in Arundhati Roy's The God of Small Things. The paper also depicts the inner life and conflicts of the self sacrificing women who desperately crave for their identity. How the female characters rebel towards the patriarchal norms and what is their ultimate fate is also highlighted in the present paper.
\end{abstract}

Keywords: Crave,conservative, identity, orthodox, patriarchal

\section{INTRODUCTION}

The growth of feminism in India has led to the questioning of the prominent old patriarchal domination. The women of today refuse to be puppets in the hands of men. Hence the image of women has undergone a drastic change. The Indian female writers have made a transition from the traditional portrayals of enduring self-sacrificing women to depiction of their inner life and subtle interpersonal relationships.The conflicting interest of man and woman in the society as a result of self-asserting women, who are engrossed in fervent search for their identity, is the hall-mark of modern portrayal of female characters. Arundhati Roy has her own opinion on society and has successfully made a mark for herself in the literary arena by her novel The God of Small Things. The novel reveals her feminist stance and her protagonist represents feminine sensibility.

In the novel, the female characters refuse to let themselves be caged inthe rules and laws set by an extremely conservative society.Ammu, the protagonist of the novel, belongs to a reputed Syrian Christian family from Kerala and she marries a Bengali Brahmin in open defiance of her family. One day, her husband loses his job but his English boss says that he would work something out if he lets him sleep with his wife Ammu. He presents this indecent proposal to Ammu and beats her when she refuses. So she divorces him and returns to his parents' home. Ammu's returning back to her parents' homedeprives her of any social position or prestige, of any right. She is treated as an unwelcome guest in her very own house where she was born and brought up.

However, the free nature of Ammu forces her to rebellion. She is fully aware of the conservative mindset of the members of her family and the society of which she is an integral part. Still she enters "the forbidden territory" to love and being loved by an untouchable- Velutha. At this act, she becomes unpardonableand makes herself susceptible to the deliberate humiliation to which she is subjected by the police Inspector as well as her own family.

\section{GENDER DISCRIMINATION}

Gender discrimination is clearly evidenced in "The God of Small Things". It is quite ironical that some exogamous marriages are considered more desirable than others. Baby KochammadespisesAmmu's husband for being Bengali and Hindu and dislikes her twins for being "Half-Hindu Hybrids whom no self-respecting Syrian Christian would ever marry" (45) but at the same time, she admires Chacko for having married an English woman and for having fathered a "beach-coloured" little angel (179). In the novel,Ammu is condemned while her very own brother Chacko is pardoned for exactly the same "crime" of exogamy resulting in divorce.This stands true in the Indian society even today.Similarly, Mammachi is frantic at the idea of Ammu in Velutha's armswhereas Chacko'srelationship with low-caste ladies of the villageis passed off as "Man's Needs" (168, 238).

Chacko is very shrewd; he takes advantage of this double standardand proudly leads his ex-wife and child into the house "like a pair of tennis trophies". Though Mammachi dislikes Margaret for her lack of social standing, she treats her grandchildren differently. Ammu's twins-Rahel and Estha are like a devalued currency to herwhile she appreciates the sterling quality of her "English" granddaughter, whom she "read[s] like a cheque" and "check[s] like a bank note" (174). 
Though both Chacko and Ammu are divorced and work for the pickle factory that their mother had set up, Chacko exhibits his full claim over the factory as well as the house and Ammu is treated like a poor relative living off the family income.

Mammachi secretly pawns her jewellery to send money to Chacko whereas Ammu is denied education. He does not like her playing violin with much expertise. Gender preference is also seen in the matter of property. Ammu, being a woman, has no claims on the pickle factory. Chacko believes that women are not fit to own property though the factory earns more profits under the guidance of Mammachi. Chacko says "What's yours is mine and what is mine is also mine" (P57).

The novel also presents thehigh cultural standards of thewest in comparison to their Indian counterparts. When Margaret, Chacko's divorced wife, comes to visit Chacko with their daughter so as torecover from the grief caused by the loss of her English husband whom she married after she had left Chacko,Ammu's children are trained to behave well in front oftheir half-English cousin- Sophie.Surprisingly, Sophie does not turn out to be as well- behaved and cultured as everybody has dreamt of. Her first question to the Indian cousins is "Does yours[your mother] hit you?" immediately followed by "Mine does," and "Mine even Slaps," to which Estha answers, "Ours doesn't." Thus, Sophie is quite modest and is excited about the prospect of playing with her cousins.

\section{LACK OF FREEDOM OF THE FEMALE}

Papachi is depicted as a tyrant who beats his wife with a brass vase. His wife is quite talented than him and he often resorts to violence in order to get rid of this inferiority complex. Even Ammu is also not spared of his tyrannical attitude. It is only Chacko who could suppress the cruelty of his father. Patriarchal dominationbecomes evident through economic oppression. Mammachi is adept at playing the violin but she could not dare to pursue her talent for fear of injuring her husband's pride. Her economic contribution to the family by setting up and successfully managing the pickle factory after her husband's retirement does not bring her any reward. After her son Chacko takes over the factory, she resigns to the position of her son's "sleeping partner". Ammu too meets the same fate. When she is ostracized due to her love affair with Velutha, she makes a living with her high school diploma as the only qualification. She is rather not allowed to claim any part of the family fortune. This lack of economic right eventually leads to her ruin and death.

Sometimes the people who are subjugated quite often plot against the oppression of people who are weaker than they are. For instance, Mammachi, who herself is the victim of patriarchal domination, exhibits great snobbery when it comes to the class question. During weddings, she often comments that the social status of the wedding party's ancestors were nothing compared to her own. Similarly, when Chacko gets married to Margaret, she is quite scornful of her as she is the daughter of a mere shopowner. She shows some sympathy towards Velutha because of her Christian background, the caste system being founded on Hinduism and because of the usefulness of his skills around the house. But she cannot forgive Ammu's affair with Velutha.

Chacko exercises his feudal rights on female labourers in the factory by demanding their bodies at night. Mammachi tacitly acknowledges his feudal rights by permitting him to use the room that has a separate entrance. He is allowed to indulge in loveless promiscuity. But when he finds out about Ammu's genuine love affair with Velutha, he feels that he has the authority and right to punish Ammu for the sake of family honor. He threatens to break every bone in Ammu's body if she steps out from the room where the family confined her after the discovery of the affair.

Rahe'l's close observation of her mother begins when she is a helpless child at the mercy of her mother's occasional nasty temper resulting from frustration. At the beginning of the story, Ammu can chastise Rahel and sometimes she gets hurt when her mother lets slip insensitive remarks. Therefore, from the beginning she observes her mother with an upward glance. Since her mother occupies an almost bottom rung in the structure of hierarchy, almost everybody else looks down on her but the narrative chooses to adopt Rahel's point of view and therefore rules out the possibility of appropriating her mother's life for her narrative aim. Rahel came back home as a divorced woman as her mother once did and her age is exactly the same as the age of her mother when she died. And towards the end of the story, she is found making love to her twin brother Estha out of sympathy as her mother made forbidden love to Velutha feeling themselves united in their sense of alienation and exclusion from the dominating forces in society. Thus Rahel is a conspiratorial focalizer.

Pappachi's treatment of his daughter highlights how his beastial violence affected "Ammu's" psyche. Pappachi is an orthodox, jealous husband. He is a fanatic and terrorizes his own family. He is a habitual wife beater whowhips his wife pitilessly either with a bras vase (P50) or his "Ivory handled riding crop (PI81). Though Mammachi suffers a lot of her husband's cruelty, she is a typical 'Indian Nari' who does not exhibit any repulsiontowards her husband and adapts herself "properly into the conventional scheme of things" (P 122). She, in fact, cries at her husband's funeral not because 'she loved him' but because "She was used to him" (P50). "With her eyes she looked in the direction that her husband looked. With her heart she looked away" (P30). 


\section{BREAKING THE BOUNDARIES}

"Ammu"", the female protagonist breaks the boundaries that confined and threatened her very existence and walks out of the unbearable circumstances. Thus, she moves from the feminist phase to the phase of displacement and self-identification. To escape the dictates of the patriarchy, the new woman comes out in more prominent contours. The new woman of India resorts to divorce as the only means of retrieving her lost life. That is what "Ammu" does in the novel.

At Ayemenem, Ammu felt like a captive lady. She is forced to quit her education because Pappachi felt that college education for a girl is an unnecessary expenditure. She gradually begins to grow desperate. "All day she dreamed of escaping from Ayemenem and the clutches of her ill-tempered father and bitter, long suffering mother. She hatched several wretched little plans. Eventually, one worked. Pappachi agreed to let her spend the summer with a distant aunt who lived in Calcutta (P38-39).

Ammu is not a "fallen" woman. She is pained to see the inability of her husband to protect her selfrespect and therefore, decides to leave him. She returns to the same dark cellar "Ayemenem" from which she wanted to run away. Destiny, once again, brings her to the place of perpetual suffering. This reflects the sensitivity of woman who tolerates everything merely for her children's sake.

The life of Ammu's mother is sandwiched between inhuman cruelties of her husband "Pappachi" and her responsibilities. That is probably the reason she embarks on a business of pickles. Thus, the novel presents an endless story of distress, pain and anguish that continues to the next generation of Rachel, Estha and Sophie Mol.

Margaret fell for Chacko's irresponsible, optimistic ways but soon is tired of the same. She rushes into marriage with him and very soon divorces him and marries Joie. She loves her daughter SohpieMol very much. After the accidental death of Sophie, she becomes a hysteric patient. Thus, the pressures, obligations, bindings etc of the women characters can be clearly noticed.

Velutha, the son of Vellyapappen, is a talented young man, who has a spirit of protest. Ammusees a great personality in him because he articulates everything which she could not herself express. She feels he is the God of small things. On the basis of this realization and being the victims of the oppressed and marginalized, both Velutha and Ammu seek solace in each other's company. But for this very act, Veluthais put to death and Ammuis separated from her children. At the age of 31, she eventually leaves for her heavenly abode.

\section{MARGINALIZATION OF WOMEN}

The novel also depicts that the fight against gender oppression leads to resistance against caste, class oppression and stimulatesanti-colonial thoughts. Such rebellious attitudes are vividly expressed through the marital and inter-gender relations of Mammachi, Baby Kochamma, Ammu and Rahel. The openly rebellious transgression of these characters outside theinstitution of marriage were very much practiced in post-colonial India and the "Love laws" lead to a questioning of the basic values and structures of the post-colonial Indian society.

Though Ammu is a middle class educated divorcee with two children, she is not welcome on her return to her father's house. She is marginalized by her very own brother Chacko-a kind of an elite leftist. She is also confined by the family structure and inheritance laws typical to the Community of Syrian Christians. Ammu is infatuated withVelutha and goes against the "Love Laws" which her community has inherited from their Hindu past. Her transgression of the caste, class and religious boundaries mounts a revolt that marginalizes her as a woman. She is treated as an outcast not only in her own family but also in the society of which she is an integral part. But, Ammu is a bold woman; she does not sccumb to the pressures of the family and the society. She, in fact, rebels against such social structures and challenges the very institution of marriage though she, later on dies exiled. She, thus becomes an epitome of all subalterns, especially women, who challenge the power structures of the social order.

Ammu is faced against a system where her "Marxist" brother Chacko exploits the poor women labourers in his factory, both financially and sexually and goes unchecked. She sees characters like Mammachi, being appropriated by patriarchal domination and be smothered and distorted by it. She sees Velutha being accused of the accidental drowning of Sophie Mol. Ammu's father is skeptical of the fact that her Bengali Hindu husband wanted to prostitute her in order to entertain his white boss. Thus Ammua subaltern woman who is economically and socially marginalized, challenges the authority of colonial rulers. Asphyxiated by social injustice, Ammu rebels against the very social norms that constitute the Syrian Christian community in Kerala. This rebellion is an act of resistance against the very foundations of this society.

Thus,Ammudefies oppressive and repressive social and political structures. Though she does not succeed in bringing about any noticeable change, shemakes a bold attempt towards realization of her dreams. Her efforts towards subalterns may not be deliberate but her actions definitely contribute to the liberation of subalterns. 
Mammachitoo exhibits some kind of resistance against patriarchal domination and marginalization. She is also a physically and psychologically abused wife, who undergoes extreme torture and trauma but never speaks out. She is not only a passive victim but is also the target of the jealousy of her entomologist husband. WhenMammachi's music teacher informs her husband that she was "exceptionally talented" and "potentially concert class" her music lessons stop abruptly. (Roy, 2005, p.67) Mammachi's strategy of utilizing patriarchal authority herself does not help her even in dealing with her son Chacko who takes away the pickle-factory from her as a kind of a consequential sequel to his saving Mammachi from her husband's beatings. Chacko replaces her and reclaims the role of the patriarch as it belongs only to the men in the family. Mammachi, in losing her factory to her son, is marginalized in terms of class and gender. A descendant of upper class Brahmins, she, however, is not a victim of caste prejudice. Marginalized by her son in old age and facing an economically disadvantaged position, Mammachi is a subaltern in more than one way. Her submission to patriarchal traditions and values are a defensive gesture rather than an honest agreement with hegemonic powers. In the Indian society, evils of caste and class and patriarchal oppressions feed and depend on each other even today. Ammu resists patriarchy and caste and class bigotry in public and pays her life.

Baby Kochamma,though converts to the Roman Catholic faith but does not dare to challenge the traditional ideas of love and marriage prevalent in post-colonial India. She does not run away to fulfil her dreams. She does not overtly believe in the rights of women as well as subalterns and makes a distinction between her self-interest and those of other women. In stark contradiction to her personal subversion and transgression of patriarchy and oppressive structures, Baby Kochammapartners with the exploitive actions against Ammu. She is responsible fortoxifyingthe minds of Mammachi and Chacko, fabrication of a false case against Velutha, deceiving the children into betraying Velutha, advising Chacko to return Estha to his father and forcing Ammu to leave. All these manipulations isolate Baby Kochamma to a wretched life where her only companion is TV. As a subaltern, she belongs to the lower middle classin terms of her power and is quite unstable in terms of class loyalty. Her abandonment of the Syrian Christian community and joining Roman Catholicism, for the sake of her love for Father Mulligan and adheringto that faith even after Father Mulligan's newly appropriated avatar of a Hindu Sadhu as well as her adoption of celibacy, speak of her interrogation of the post-colonial Indian social order apparent in Kerala.

Estha and Raheltoo are subalterns in the sense of being rootless economically, financially, in terms of family, lineage and culture. Being deprived of fatherly love and a stable economic base, they have to fall back upon each other. They have a battered childhood because of their father's "drunken violence followed by postdrunken badgering". The two children had a double stigma of mixed parentage attached to them, both "religious (because their father was Hindu and mother Syrian Christian) and ethnic(their father being a Bengali and mother, a Keralite)." (Roy, 1997, p. 91) Moreover, they were the children of divorced parents. They were deprived of conventional parental love.

After Ammu's death, Estha is sent back to his father and the twins face the pain of separation. Thus, they spend their childhood in an altogether different manner, learning"how history negotiates its terms and collects its dues from those who break its laws." (p. 55) Rahelfaces a tough time in school and is expelled three times. Thus, she is marginalized because of her religion/community, gender, class and age and can be truly labelled as the subaltern. Her acts of non-conformity can be considered as acts of resistance through which she wants to bring about some kind of change. The most important act by Rahel is that of accomplishing her incestuous love for her twin brother, Estha, which though an act of personal self-assertion, is also extremely political and challenges the local inequalities in post-colonial India.

Thus, Mammachi, Baby Kochamma, Ammu and Rahel, question the indigenous normsassociated with patriarchy, class, caste and feudal-capitalist economic structures. Surprisingly, these women do not support global inequality veiled as globalization. Ammu refuses to be a prostitute to the white boss of her husband. Mammachi feels threatened by whatever happens on the television. Baby Kochamma does not accept every change in the identity of Father Mulligan. She accepts Roman Catholicism for his sakebut does not switch back to Hinduism, when Father Mulligan, becomes a Hindu Sadhu. Rahellooks forward to the arrival of her twin brother Estha and tries to heal him of his dumbness and fractured existence and accomplishes their childish but incestuous love- an act of complete denial of the restrictive permissive sexuality of the West that binds sexuality with business, transaction and money. Thus, Rahelchallenges the global inequalities and dominationcamouflaged as globalization.

\section{CONCLUSION}

The novel depicts women as subalterns, some of whom try to confront the existing social inequalities in order to bring about a change. Though they lack articulate voice of the members of other groups in Indian society, theychallenge the existing local and global inequalities prevalent in the society.They question the structures of caste, class and gender in all respects merely by their personal involvement in different issues. 
Thus, Arundhati Roy's female characters are torn between traditional boundaries and modern free zones. Through her novel, she has beautifully affirmed that a woman too, is a living entity not an appendage of man. She is an independent being, who is bestowed with the capacity to tread her own path to salvation.

The representation of the subaltern woman by Roy has been made more varied, merely by presenting the various portraits of women who, in spite of their oppression and marginalization, are not without agency or responsibility. Ammu represents people who actually dare to do 'the unthinkable', to transgress the very line that upholds the system of difference that casteism inherently maintains. She represents all those who have suffered due to transgressions against the 'Love Laws' and gender-specific expectations imposed upon them.Ammu and Velutha are representatives of thousands of cross-caste relationships in the real India, a voice that resonates all over the world.

\section{REFERENCES}

[1] Ahmad, Aijaz. Reading Arundhati Roy politically, in Murari Prasad (ed.) Arundhati Roy: Critical perspectives.(New Delhi: Pencraft International, 2006).

[2] Al- Quaderi, GolamGaus\& Md. Saiful Islam. "Complicity and resistance: Women in Arundhati Roy's The God of Small Things". Journal of Postcolonial Cultures and Societies (JPCS),2(4), 2011, 62-78.

[3] Alam, Khurshid. "Untouchables" in The God of Small Things.5.6.2007. 2001. Retrieved from http://www.usp.nus.edu.sg/post/india/roy/alum1.html.

[4] Bose, Brinda.In desire and in death: Eroticism as politics in Arundhati Roy's The God of Small Things, in Murari Prasad (edited). Arundhati Roy: Critical perspectives, (New Delhi: Pencraft International, 2006).

[5] Dodiya, Jaydipsinh\&JoyaChakravarthy (eds.)TheCritical Studies of Arundhati Roy's “The God of Small Things”. (New Delhi: Atlantic Publishers and Distributors, 2001).

[6] Dwivedi, O.P."The Subaltern and the text: ArundhatiRoyes she God of Small Things". Journal of Asia Pacific Studies, 1(2), 2010.387-394.

[7] Navarro-Tejero, Antonia. Power Relationships in The God of Small Things, in Murari Prasad (edited). Arundhati Roy: Critical perspectives. (New Delhi: Pencraft International, 2006).

[8] Roy, Amitabh.The God of Small Things: A novel of social commitment. (New Delhi: Atlantic Publishers and Distributors, 2005).

[9] Roy, Arundhati.The God of Small Things.(London: Flamingo, 1997).

[10] Subhashini, A. "Feminine Sensitivity with reference to The God of Small Things".SRR and CVR Government College E Research Journal.2(1), 2011.

[11] Surendran, K.V.The God of Small Things: A saga of lost dreams. (New Delhi: Atlantic Publishers and Distributors, 2009).

[12] Thakur, Bhoomika. "Portrayal of Women in the Novels of Desai, Deshpande, Markanday and Roy"ResearchJournal of English Language and Literature (RJELAL)1(2), 2013, 208-211. 